\title{
Melatonin: The First Noninvasive Causal Therapy for Both Endometriosis and Adenomyosis?
}

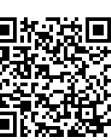

\author{
Jan Tesarik ${ }^{1 *}$ and Raquel Mendoza-Tesarik ${ }^{1,2}$ \\ ${ }^{1}$ MARGen Clinic, Granada, Spain \\ ${ }^{2}$ University of Granada, Spain
}

Submission: September 17, 2018 ; Published: September 26, 2018

*Corresponding author: Jan Tesarik, MARGen Clinic, University of Granada, Spain, Email: jtesarik@clinicamargen.com

Abstract

Recently published data show that in vitro exposure of human normal and endometriotic endometrial epithelial cells to melatonin inhibits $17 \beta$-estradiol-induced cell signaling pathways leading to their epithelial-mesenchymal transition, suggesting that melatonin might be used as a causative treatment agent for endometriosis. However, the same aberrant response of endometrial epithelial cells to $17 \beta$-estradiol is intimately associated with the pathophysiology of adenomyosis, another challenging issue to both clinicians and researchers. The eventual $I n$ vitro effects of melatonin on epithelial-mesenchymal transition and the reverse process, mesenchymal-epithelial transition of adenomyotic cells obtained by biopsy, remain to be evaluated. Moreover, clinical research into the effects of melatonin in women suffering from endometriosis and adenomyosis, including dose-finding studies, should be encouraged.

Keywords: Endometriosis; Adenomyosis; Melatonin; Epithelial-mesenchymal transition; Mesenchymal-epithelial transition; $17 \beta$-estradiol; Migration and invasion

Abbreviations: EMT: Epithelial-Mesenchymal Transition; TGF: Transforming Growth Factor

\section{Introduction}

It was shown recently that melatonin inhibits $17 \beta$-estradiolinduced migration, invasion and epithelial-mesenchymal transition in normal and endometriotic human endometrial epithelial cells [1]. These data suggest that melatonin may become the first noninvasive therapy which can be used to treat the very cause of endometriosis and not just to alleviate its symptoms. However, the beneficial effect of melatonin, in addition to endometriosis, can be expected exert similar effects in adenomyosis, another closely related pathology in which abnormally reactive endometrial epitelial cells are major players. In fact, the similarity of the respective pathophysiological mechanisms of endometriosis and adenomyosis [2] suggests that melatonin may also be useful to treat adenomyosis, another disease caused by aberrant behaviour of endometrial epithelial cells in response to $17 \beta$-estradiol. As for endometriosis, no noninvasive causal treatment for adenomyosis has not been made available so far.

Both endometriosis and adenomyosis are characterized by a profound alteration of cell signaling pathways, activated or silenced by $17 \beta$-estradiol, leading to epithelial-mesenchymal transition (EMT) of the endometrial epithelial cells. As a result of these alterations, the endometrium-derived cells acquire the ability to migrate to ectopic locations, to invade the adjacent tissues and to become resistent to apoptosis [3-4]. EMT is a physiological process, involved in normal functioning of the female reproductive organs, but its dysregulation can lead to pathological conditions, such as endometriosis, adenomyosis, and carcinogenesis [5].

The findings by Qi et al. [1] show that melatonin counteracts the estradiol-induced activation of the Notch pathway, which is a key signaling pathway not only in EMT but also in the reverse process, referred to as mesenchymal-epithelial transition (MET). The latter is associated with a loss of cell migratory freedom, restriction of invasiveness and cancer regression [6]. The finding that, in addition to estradiol-induced EMT, melatonin abolishes EMT induced by transforming growth factor (TGF)- b1 [1] suggests that melatonin may also be effective against cancer. Interestingly, melatonin has recently been shown to suppress fibrotic responses of a human mucoepidermoid cell line to TGF-b1 [7], suggesting that this drug may be involved in both EMT and MET regulations. These properties make melatonin an interesting candidate for both the prevention and treatment of endometriosis [1] and adenomyosis [8-10].

\section{Conclusion}

the study by Qi et al. [1] should encourage further In vitro studies evaluating the effects of melatonin on the EMT and MET processes in human cells obtained by biopsy of organs affected by different invasive pathologies, including adenomyosis and cancer. 
Independently, the time appears ready for designing clinical dosefinding studies on In vivo effects of melatonin on endometriotic and adenomyotic cells from affected women.

\section{References}

1. Qi S, Yan L, Liu Z, Mu YI, Li M, et al. (2018) Melatonin inhibits $17 \beta$-estradiol-induced migration, invasion and epitelial-mesenchymal transition in normal and endometriotic endometrial epithelial cells. Reprod Biol Endocrinol 16(1): 62.

2. Leyendecker G, Wildt L, Mall G (2009) The pathophysiology of endometriosis and adenomyosis: tissue injury and repair. Arch Gynecol Obstet 280(4): 529-538.

3. Chen YJ, Li HY, Huang CH, Twu NF, Yen MS, et al. (2010) Oestrogeninduced epithelial-mesenchymal transition of endometrial epithelial cells contributes to the development of adenomyosis. J Pathol 222(3): 261-270.

4. Benagiano G, Brosens I, Habiba M (2014) Structural and molecular features of the endomyometrium in endometriosis and adenomyosis. Hum Reprod Update 20(3): 386-402.
5. Bilyk O, Coatham M, Jewer M, Postovit LM (2017) Epithelial-tomesenchymal transition in the female reproductive tract: From normal functioning to disease pathology. Front Oncol 7:145.

6. Nieto MA, Huang RY, Jackson RA, Thiery JP (2016) EMT: 2016. Cell 166(1): 21-45.

7. Shin NR, Park JW, Lee IC, Ko JW, Park SH, et al. (2017) Melatonin suppresses fibrotic responses induced by cigarette smoke via downregulation of TGF- $\beta 1$ Oncotarget 8(56): 95692-95703.

8. Zhou W, Peng Z, Zhang C, Liu S, Zhang Y, et al. (2018) ILK-induced epithelial-mesenchymal transition promotes the invasive phenotype in adenomyosis. Biochem Biophys Res Commun 497(4): 950-956.

9. Viswanathan AN, Schernhammer ES (2009) Circulating melatonin and the risk of breast and endometrial cancer in women. Cancer Lett 281(1): 1-7.

10. Chuffa LGA, Reiter RJ, Lupi LA (2017) Melatonin as a promising agent to treat ovarian cancer: molecular mechanisms. Carcinogenesis 38(10): 945-952.

\section{Your next submission with Juniper Publishers will reach you the below assets}

- Quality Editorial service

- Swift Peer Review

- Reprints availability

- E-prints Service

- Manuscript Podcast for convenient understanding

- Global attainment for your research

- Manuscript accessibility in different formats

( Pdf, E-pub, Full Text, Audio)

- Unceasing customer service

Track the below URL for one-step submission https://juniperpublishers.com/online-submission.php 